\title{
A study on the performance of PV/T system based on windows
}

\author{
X.P. HUAN ${ }^{1}$ \& S.G. ZHU' \& H.L. ZHANG ${ }^{1}$ \& X.Z. LIU², A.Z. SUN ${ }^{2}$ \\ ${ }^{1}$ School of Energy and Power Engineering, Nanjing University of Science and Technology, China \\ ${ }^{2}$ Lianyungang Research Institute, Nanjing University of Science and Technology, China
}

KEYWORD: PV/T based on windows; Monocrystalline silicon; Building energy conservation ABSTRACT: A PV/T system based on windows is designed and fabricated to investigate the performance of PV/T system and the influence on the energy saving effect in Nanjing. A water-cooling device is installed behind the PV cells to improve the power generation efficiency and its cooling effect is better than air-cooling. Experiments on the PV/T system in every season are performed in this paper. The energy consumption of the test room with normal glass windows and PV/T based windows is compared, and the seasonal power saving effect under different cooling conditions is summarized. It is concluded that the best energy saving effect of PV/T system can be achieved by using different cooling water flow rate in several seasons.

\section{INTRODUCTION}

According to incomplete statistics, 50\% of global energy is consumed in the construction and use of buildings [1]. A large part of building energy consumption is caused by the heat exchange between external envelope structure and outdoor environment, thus reducing heat loss from the building envelope is an important direction in the field of building energy conservation [2][3].

Compared with other external envelope structure, the thermal insulation performance of window is the worst. Since the 21 st century, more and more research related is carried out: The influence of photovoltaic cells surface temperature on the output efficiency has been investigated [4][5]. By the way of natural ventilation cooling, the surface temperature of PV cells can reduce $15{ }^{\circ} \mathrm{C}$ and the output efficiency of PV cells will increase $8.3 \%$. A new parameter photovoltaic effect (PVEF) is presented to evaluate the overall performance of photovoltaic curtain wall by theoretical study [6]. The simulation method was used to study the photovoltaic, photo-thermal and daylighting performance of the ventilated double-glass PV windows by Remi.C, etc. [7]. In the development of PV ventilated window, the performance evaluation of a PV ventilated window applying to office building has been investigated [8]. The results show that the best energy-saving effect of system in Hong Kong can be achieved by using air conditioning for controlling the indoor temperature and the transmittance of PV cells is $45 \%-55 \%$.

A PV/T system based on windows is designed and fabricated to investigate the performance of PV/T system and the influence on the energy saving effect, which provides theoretical basis for its popularization and application.

\section{PV/T SYSTEM BASED ON WINDOWS}

\section{System composition}

The system consists of smart windows system, PV cells, glazing, water-cooled heat exchanger, collector tanks, pump and other equipment. 


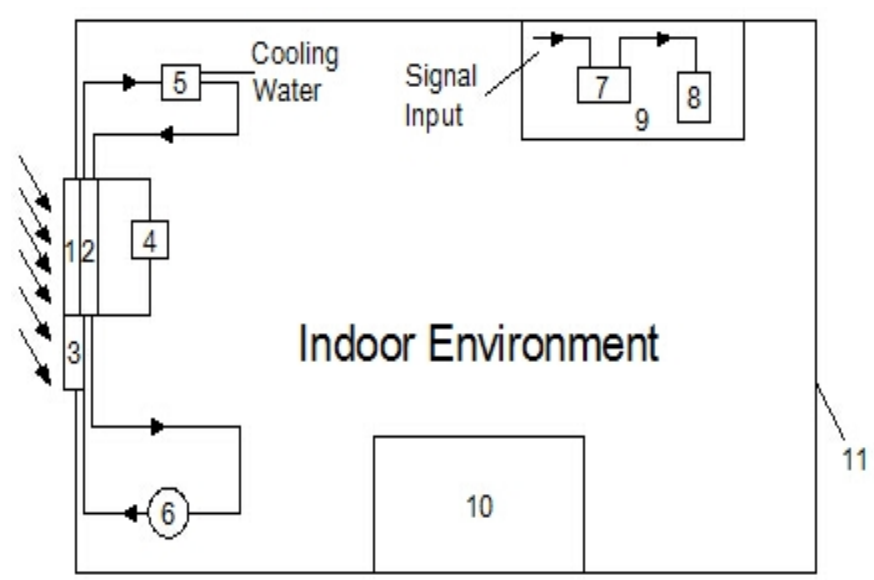

Figure 1. System schematic diagram

1-PV cells 2-water-cooleads heat exchanger 3-glass window 4-accumulator 5-collector tank 6-pump

7, 8-data acquisition system 9-test board 10-sample shelf of smart windows 11-door

As shown in Figure 1, the PV cells 1 is set to receive solar radiation. Most of the solar energy is absorbed by the PV cells' surface and then be converted into electrical energy and thermal energy. The electrical energy is stored in the battery 4 and the thermal energy leads to the temperature rise of solar cells surface. In order to improve the power efficiency of battery, water-cooled radiator 2 is installed on the back of PV cells to reduce the surface temperature of the cells; the hot water collected can be used for life. This means that we can get electricity and heat at the same time. Compared with traditional PV/T system, this system is mainly installed on windows to realize the purpose of energysaving and building integrated.

\section{Solar collecting system design}

A board type water-cooling radiator is designed to get higher generating efficiency of the solar cells. This design also takes into account the thermal efficiency of the system and the combination of water-cooling radiator and PV cells. The internal radiator is a circular channel, water flow through the channel to absorb the heat of radiator plate surface. Side of the collector plate is covered with insulation material to reduce heat dissipation. Radiator parameters are selected in accordance with the solar irradiance of Nanjing and the basic requirement of the cooling water outlet temperature.

\section{Water pump selection}

This paper selects a miniature magnetic drive gear pumps, its flow is $50-900 \mathrm{~mL} / \mathrm{min}$ and the head is $5 \mathrm{~m}$.

\section{Mounting base design}

The mounting base is designed and fabricated based on the window structure of testing room. Window frame is fixed to the wall with 20 bolt holes around it and the size of bolt hole is $5 \mathrm{~mm}$. The diameter of the bolt used is $8 \mathrm{~mm}$ and the length is $12 \mathrm{~mm}$. The overall size and shape of the window frame are shown in Figure 2. By controlling the removal and installation of bolts, nuts and gasket, the windows and PV cells can be easily removed and installed.

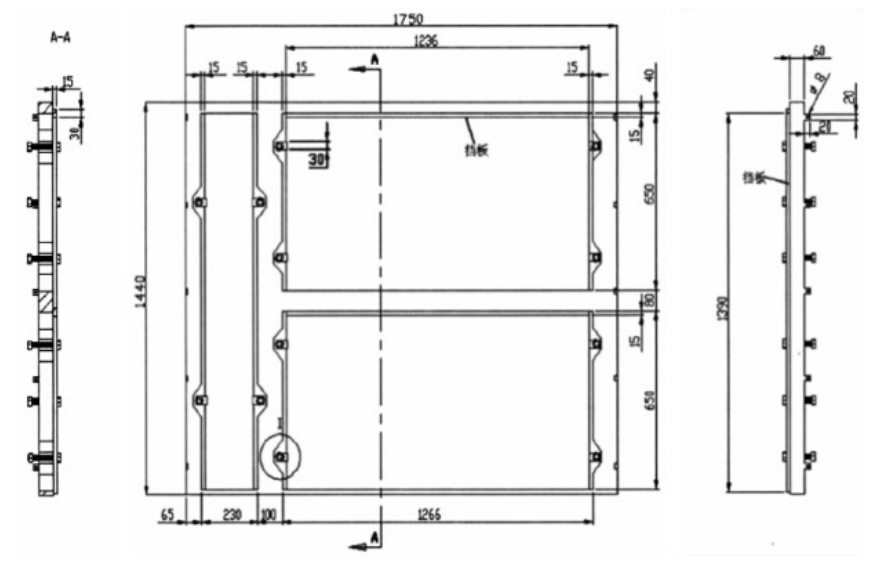

Figure 2. The overall size and shape of the window frame. 


\section{PV power generation and energy storage system design}

This system consists of monocrystalline silicon PV cells, batteries, regulators, a power meter and other components.

The size of cells is selected on the basis of the window frame mentioned above; its characteristic parameters are shown in Table 1.

Table 1. Parameters of monocrystalline silicon PV cells.

\begin{tabular}{ccccc}
\hline $\mathrm{P}_{\text {MAX }}(\mathrm{W})$ & $\begin{array}{c}\text { Max pow- } \\
\text { er vol- } \\
\text { tage(V) }\end{array}$ & $\begin{array}{c}\text { Max } \\
\text { power } \\
\text { current(A) }\end{array}$ & $\mathrm{V}_{\mathrm{OC}}(\mathrm{V})$ & $\begin{array}{c}\mathrm{I}_{\mathrm{SC}} \\
(\mathrm{A})\end{array}$ \\
\hline 105 & 36 & 2.92 & 44.5 & 3.31 \\
\hline
\end{tabular}

\section{Test system}

Experimental test system consists of optical test, circuit test and temperature test. A light meter is used to measure solar power in the optical test. A set of PV testing and energy storage system is used in the circuit test. Copper-constantan T type thermocouples are used to measure the temperature of various components in temperature test. Its measuring range is $-300^{\circ} \mathrm{C} \sim+300^{\circ} \mathrm{C}$ and accuracy is $0.1^{\circ} \mathrm{C}$.

\section{EXPERIMENT PROCESS AND TEST METHOD}

At the beginning of experiment, the water-cooling radiator and PV cells fit closely by using thermal conductive silicone and then be placed in the window frame. Three different cooling water flow rate $(340 \mathrm{~mL} / \mathrm{min}(\mathrm{n}=1000 \mathrm{r}), 680 \mathrm{~mL} / \mathrm{min}(\mathrm{n}=2000 \mathrm{r}), 1024 \mathrm{~mL} / \mathrm{min}(\mathrm{n}=3000 \mathrm{r}))$ are set in order to research the generation characteristics of PV cells under different cooling conditions. The cooling water flow rate can be controlled by adjusting the rotating speed of the micro water pump $(0.034 \mathrm{~kg} / \mathrm{RPM})$. According to theoretical analysis, the total heat gain of test room includes three parts: heat transfer of the window, heat transfer of the wall and heat transfer of the door. When decorate the thermocouple, its head (sensing part) is glued to the wall with sticky tinfoil which covered with thermal insulation cotton.

The area of test room, widow and PV cells is $20 \mathrm{~m}^{2}, 2.4 \mathrm{~m}^{2}$ and $0.84 \mathrm{~m}^{2}$ respectively. The system runs 9 hours a day during the spring and autumn, 10 hours a day during the summer and 8 hours a day during the winter.

\section{RESULTS AND DISCUSSION}

\section{The results and analysis of summer experiment}

The experiment of summer was carried out in three consecutive days from 8:00 am to 5:30 pm, August 2 to August 4, 2014. The weather was fine, and the light conditions were similar during the experiment. The results are shown in Table 2.

Table 2. The results of summer experiment. (daily average)

\begin{tabular}{cccccc}
\hline $\begin{array}{c}\text { CWFR } \\
(\mathrm{mL} / \mathrm{min})\end{array}$ & $\begin{array}{c}\text { TSR } \\
(\mathrm{MJ})\end{array}$ & $\begin{array}{c}\text { SPG } \\
(\mathrm{MJ})\end{array}$ & SGE & $\begin{array}{c}\text { IHG } \\
(\mathrm{MJ})\end{array}$ & $\begin{array}{c}\text { CWHG } \\
(\mathrm{MJ})\end{array}$ \\
\hline 340 & 12.83 & 0.98 & $7.67 \%$ & 5.48 & 0.65 \\
680 & 13.47 & 1.05 & $7.84 \%$ & 5.45 & 0.72 \\
1024 & 13.55 & 1.14 & $8.41 \%$ & 5.39 & 0.78 \\
\hline
\end{tabular}

Note: FR - Cooling water flow rate, TSR-Total solar radiation, SPG-System power generation, SGE-System generation efficiency, IHG-Indoor heat gain, CWHG-Cooling water heat gain. The electrical energy has been converted into heat; the total amount of the circulating cooling water is $20 \mathrm{~kg}$.

As shown in the Table 2, the cooling water heat gain increases with rising pump rotating speed, because the heat exchange capacity of the cooling water enhances with the increase of flow rate. As the cooling water flow rate raises, the radiator surface temperature drops and indoor air convection heat 
transfer reduces, which led to the reduction of indoor heat gain. Besides, the temperature of solar cells falls as the cooling water heat gain rises, the generation efficiency and generating capacity of system improves. The power consumption of the pump increases with the rising of cooling water flow rate. Energy saving statistics of system in summer is shown in Table 3.

Table 3. Energy saving statistics of system in summer.

\begin{tabular}{cccccc}
\hline Condition & $\begin{array}{l}\text { IHG } \\
(\mathrm{MJ})\end{array}$ & $\begin{array}{c}\text { RHR } \\
(\mathrm{MJ})\end{array}$ & $\begin{array}{c}\text { SPG } \\
(\mathrm{MJ})\end{array}$ & $\begin{array}{c}\text { CWHG } \\
(\mathrm{MJ})\end{array}$ & $\begin{array}{c}\text { PPC } \\
(\mathrm{MJ})\end{array}$ \\
\hline normal glass & 7.83 & 0 & 0 & 0 & 0 \\
condition1 & 5.48 & 2.35 & 0.98 & 0.65 & 0.51 \\
condition2 & 5.45 & 2.38 & 1.05 & 0.72 & 0.63 \\
condition3 & 5.39 & 2.44 & 1.34 & 0.78 & 0.69 \\
\hline
\end{tabular}

Note: RHR-Relative heat reduction, PPC-Pump power consumption. Condition $1 \& 2 \& 3$ are both monocrystalline silicon solar cells with different cooling water flow rate, and the flow rate is $340 \mathrm{~mL} / \mathrm{min}, 680 \mathrm{~mL} / \mathrm{min}$ and $1024 \mathrm{~mL} / \mathrm{min}$ respectively. (similarly hereinafter)

\section{The results of spring/autumn experiment}

Considering the similar situation of spring and autumn in Nanjing, only the autumn experiment was carried out. The experiment of autumn was carried out from September 27 to September 30 with good lighting condition. The results are shown in Table 4.

Table 4. The results of autumn experiment. (daily average)

\begin{tabular}{ccccc}
\hline $\begin{array}{c}\text { CWFR } \\
(\mathrm{mL} / \mathrm{min})\end{array}$ & TSR & SPG & SGE & CWHG \\
340 & 7.83 & 0.57 & $7.37 \%$ & 0.58 \\
\hline 680 & 8.13 & 0.64 & $7.90 \%$ & 0.62 \\
1024 & 7.96 & 0.66 & $8.39 \%$ & 0.69 \\
\hline
\end{tabular}

Note: the total amount of the circulating cooling water is $15 \mathrm{~kg}$.

Energy saving statistics of system in autumn is shown in Table 5

Table 5. Energy saving statistics of system in autumn.

\begin{tabular}{lccc}
\hline \multicolumn{1}{c}{ Condition } & $\begin{array}{c}\text { SPG } \\
(\mathrm{MJ})\end{array}$ & $\begin{array}{c}\text { CWHG } \\
(\mathrm{MJ})\end{array}$ & $\begin{array}{c}\text { PPC } \\
(\mathrm{MJ})\end{array}$ \\
\hline condition1 & 0.57 & 0.58 & 0.51 \\
condition2 & 0.64 & 0.62 & 0.63 \\
condition3 & 0.66 & 0.69 & 0.69 \\
\hline
\end{tabular}

\section{The results of winter experiment}

The experiment of autumn was carried out from November 28 to November 30 with good lighting condition. The results are shown in Table 6.

Table 6. The results of winter experiment (daily average).

\begin{tabular}{ccccc}
\hline $\begin{array}{c}\text { CWFR } \\
(\mathrm{mL} / \mathrm{min})\end{array}$ & $\begin{array}{c}\text { TSR } \\
(\mathrm{MJ})\end{array}$ & $\begin{array}{c}\text { SPG } \\
(\mathrm{MJ})\end{array}$ & SGE & $\begin{array}{c}\text { CWHG } \\
(\mathrm{MJ})\end{array}$ \\
\hline 340 & 7.06 & 0.48 & $6.87 \%$ & 0.56 \\
680 & 6.98 & 0.49 & $7.06 \%$ & 0.58 \\
1024 & 6.92 & 0.53 & $7.42 \%$ & 0.62 \\
\hline
\end{tabular}

Note: the total amount of the circulating cooling water is $10 \mathrm{~kg}$. Energy saving statistics of system in winter is shown in Table 7. 
Table 7. Energy saving statistics of system in winter.

\begin{tabular}{cccccc}
\hline Condition & $\begin{array}{c}\text { IHG } \\
\text { (MJ) }\end{array}$ & $\begin{array}{c}\text { RHR } \\
(\mathrm{MJ})\end{array}$ & $\begin{array}{c}\text { SPG } \\
(\mathrm{MJ})\end{array}$ & $\begin{array}{c}\text { CWHG } \\
\text { (MJ) }\end{array}$ & $\begin{array}{c}\text { PPC } \\
(\mathrm{MJ})\end{array}$ \\
\hline normal & 1.43 & 0 & 0 & 0 & 0 \\
glass & & & & & \\
condition1 & 1.35 & 0.08 & 0.48 & 0.56 & 0.51 \\
condition2 & 1.16 & 0.27 & 0.49 & 0.58 & 0.63 \\
condition3 & 1.09 & 0.34 & 0.53 & 0.62 & 0.69 \\
\hline
\end{tabular}

\section{Economic benefit analysis}

With the increase of cooling water flow rate, the cooling water heat gain increases, the temperature of solar cells drops and power generation efficiency increases, which leads to the increase of power generation; At the same time, the pump power consumption and the relative indoor heat gain reduction of the test room increase with the increase of cooling water flow rate. The economic benefit of system is related to the several factors above. In order to better evaluate the economic performance of the system, a concept of "Equivalent electric net-benefit (EENB)" is introduced in this paper. The relative indoor heat gain reduction of the test room is equivalent to air conditioning work $(\mathrm{COP}=2.5)$. Seasonal equivalent electric net-benefit of system can be calculated by using the equations given below.

$$
\begin{aligned}
& \text { EENB }=\frac{C W H G}{3.6}+\left(P-P_{p}\right) \\
& \text { EENB }=\frac{C W H G}{3.6}+\frac{R H R}{2.5 \times 3.6}+\left(P-P_{p}\right) \quad(\text { Eq.4-2) } \\
& \text { EENB }=\frac{C W H G}{3.6}-\frac{R H R}{2.5 \times 3.6}+\left(P-P_{p}\right) \quad(\text { Eq.4-3) }
\end{aligned}
$$

Note: $\mathrm{P}(\mathrm{kW} \cdot \mathrm{h})$ is the power generation, $P p(\mathrm{~kW} \cdot \mathrm{h})$ is the pump power consumption. Eq.4-2 is used for spring and autumn while Eq.4-2 and Eq.4-3 is used for summer and winter respectively.

Seasonal equivalent electric net-benefit of system under different cooling conditions is shown in Figure 3.

As shown in Figure 3, there is a positive correlation between the parameters of the system and cooling water flow rate. However, the change range of relative indoor heat gain reduction and pump power consumption is greater than that of system power generation and cooling water heat gain in winter, therefore, the maximal EENB of system appears at the flow rate of $340 \mathrm{~mL} / \mathrm{min}$. In other seasons, the maximal EENB appears at the flow rate of $1020 \mathrm{~mL} / \mathrm{min}$. The maximal EENB of experimental system is $105.6 \mathrm{~kW} \cdot \mathrm{h}$ for a year.

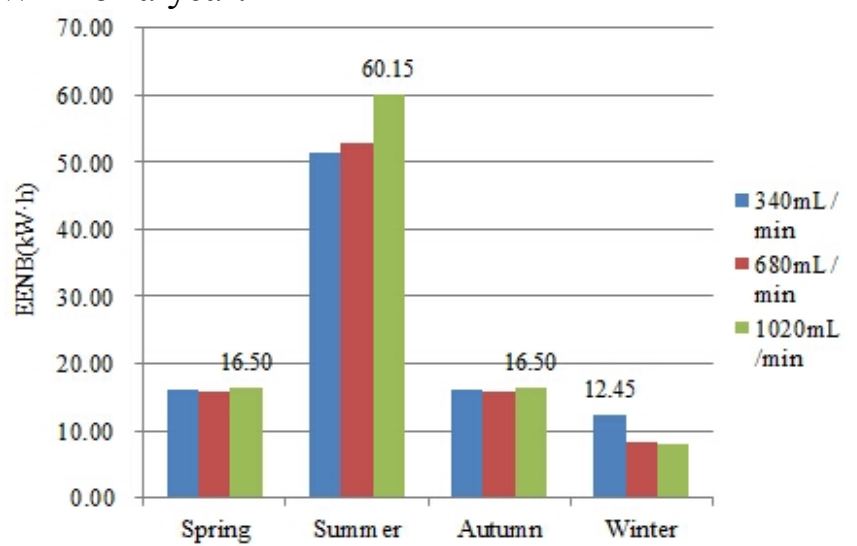

Figure 3. Seasonal EENB of system under different cooling conditions.

In addition, it is assumed that the cooling water is driven by the hydraulic head of tap water and the indoor heat gain, system power generation and cooling water heat gain are changeless, seasonal EENB of system is shown under this condition in Figure 4 (the cooling water flow is assumed to be $340 \mathrm{~mL} / \mathrm{min}$ ). 


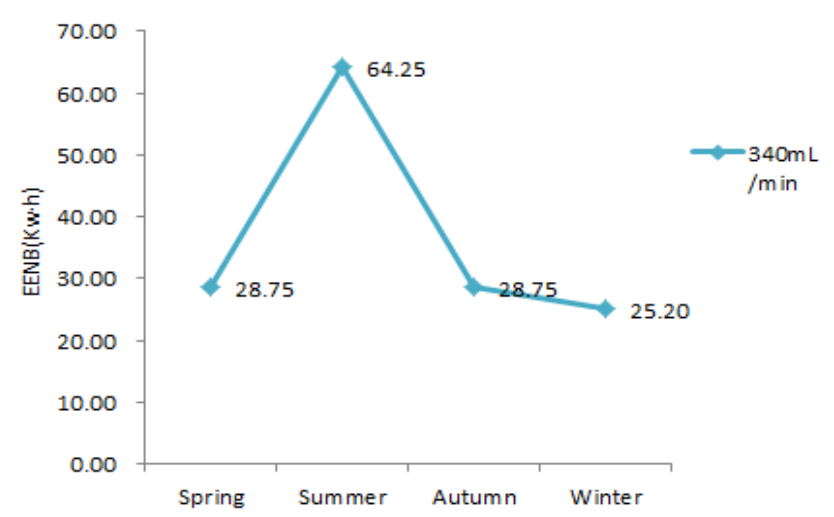

Figure 4. Seasonal EENB of system without pump.

As shown in Figure 4, if the hypothesis is true, the EENB of system without pump is $146.95 \mathrm{~kW} \cdot \mathrm{h}$ for a year, which is $39.16 \%$ higher than the maximum of experimental system.

\section{CONCLUSION}

A PV/T system based on windows is designed and fabricated by the author to investigate the performance of PV/T system and the influence on the energy saving effect. The performance analysis of its application in a small room was done. The following summarizes the findings:

The power generation of system increases with the rising of the pump rotating speed, because the heat exchange capacity of the cooling water enhances as the flow rate goes up, which leads to the decreasing of solar cells' temperature and the increasing of generation efficiency.

The indoor heat gain reduction can reduce air conditioning energy consumption and the increase of cooling water heat gain can also provide part of the hot water, which can indirectly save energy.

The optimal cooling condition can be drawn from the economic benefit analysis: the cooling water flow rate is $340 \mathrm{~mL} / \mathrm{min}$ in winter and $1020 \mathrm{~mL} / \mathrm{min}$ in other seasons. The best energy saving effect can be achieved under the optimal cooling condition and the maximal EENB of PV/T system is $105.6 \mathrm{~kW} \cdot \mathrm{h}$ for a year in Nanjing.

\section{ACKNOWLEDGMENT}

This work is supported by the Innovation Fund of University-Industry Cooperation (Prospective joint research project, Lianyungang, Jiangsu Province, No.BY2013047), the Innovation Fund of University-Industry Cooperation (High efficient energy saving project, Lianyungang, Jiangsu Province, No. CXY1327) and the Foundation of State Key Laboratory of Coal Combustion (No. FSKLCC1109).

\section{REFERENCE}

[1] HE Chenglong, CAO Ping. A study on the Building Energy Saving Integrated Management System. Construction Economy. 2006(11): 25-27. (in Chinese)

[2] WANG Shizhong, GUAN Ming. The key of glass-building energy conservation. Architectural Glass And Functional Glass. 2005(4): 3-8. (in Chinese)

[3] XIE Hairong. Theoretical analysis and experimental research on the energy consumption of solar-control film glass. Hunan: Hunan University, 2007. (in Chinese)

[4] Brinkworth, B.J. Cross, B.M., Marshall, R.H., Yang, H. Thermal regulation of photovoltaic cladding. Solar Energy, 1997, 61(3): 169-178.

[5] Yang H.X., Marshall R.H., Brinkworth B.J., Validated simulation for thermal regulation of photovoltaic wall structures. Proc of the 25th photovoltaic specialist conference, USA, 1996, 14531456. 
[6] Geun Y.Y, Mike.M, Koen.S, Design and overall energy performance of a ventilated photovoltaic façade. Solar Energy, 2007: 81: 383-394.

[7] Remi.C, Andread.K, Athienitis, Optimization of the performance of double-facades with integrated photovoltaic cells and motorized blinds. Solar Energy, 2006, 80: 482-491.

[8] T.T.ChoW, K.F.Fong, W.He et a1. Performance evaluation of a PV ventilated window applying to office building of Hong Kong. Energy and Buildings, 2007, 39(6): 643-650. 